\title{
From Sierra to Coast: Tracing the supply of medicinal plants in Northern Peru - A plant collector's tale
}

\author{
Zachary Revene, Rainer W. Bussmann and Douglas Sharon
}

\section{Research}

\begin{abstract}
Northern Peru represents the center of the Andean "health axis", where the continuous use of more than 500 medicinal plants has been documented. Local healers as well as patients purchase a large part of their plants in local markets. While limited data exist with regard to market inventories, no information has been available on how the plants get to the markets, if they are cultivated or collected in the wild, and what kind of income the collectors receive.

The present paper reports on the complete market flow from collection to middlemen to vendor from the perspective of a herb collector/vendor. Herbs were mostly collected wild in the highlands around the city of Cajamarca, and collection as well as transport to the coastal markets required long-distance travel. The average daily net income of the collector varied from US\$2.80 to 6.45. Even the upper end of this range is hardly sufficient to provide for a family. The low income indicates that the herb trade is very fragile, since collectors might either decide to engage in higher income activities or higher turnover, which could easily lead to over-harvesting of rare medicinal species in the region.
\end{abstract}

\section{Resumen}

Perú Septentrional representa el centro del "eje de salud" andino donde el uso continuo de más de 500 plantas medicinales ha sido documentado. Los curanderos locales y clientes compran una gran parte de sus plantas en los mercados locales. Dado que datos limitados existen en cuanto a inventarios de los mercados, ninguna información ha sido disponible sobre la manera como las plantas llegan a los mercados, si son cultivadas o coleccionadas silvestres y que tipo de remuneración reciben los coleccionistas. El trabajo presente reporta el movimiento completo de la colecta a los medidores y a los vende- dores desde la perspectiva de un coleccionista/vendedor de yerbas. En la mayoría de los casos las yerbas fueron coleccionadas silvestres en la sierra en los alrededores de la ciudad de Cajamarca y tanto la colecta como el transporte a los mercados de la costa requirieron viajes de larga distancia. El promedio insumo diario neto de la coleccionista varió entre US\$2.80 a 6.45. Apenas aun la cifra más alta de este rango sea insuficiente para que una familia puede subsistir. El insumo tan bajo indica que el comercio de yerbas es muy frágil, dado que los coleccionistas podían decidir dedicarse a otras actividades más lucrativas por mayor rendimiento lo que fácilmente podía resultar en la sobre-cosecha de las especies raras de la región.

\section{Introduction}

Traditional medicine is used globally and has a rapidly growing economic importance. In developing countries, traditional medicine is often the only accessible and affordable treatment available. In Latin America, the WHO Regional Office for the Americas (AMRO/PAHO) reports

\section{Correspondence}

Zachary Revene, 112413 Pleasant Run Terrace, Richmond, Virginia 23233, U.S.A.

honeybadger33@yahoo.com

Rainer W. Bussmann, William L. Brown Center for Plant Genetic Resources, Missouri Botanical Garden, P.O. Box 299, St. Louis, MO 63166-0299, U.S.A.

rainer.bussmann@mobot.org

Douglas Sharon, 2328 Dolphin Dr., Richmond, California 94804, U.S.A.

Ethnobotany Research \& Applications 6:015-022 (2008) 
that $71 \%$ of the population in Chile and $40 \%$ of the population in Colombia have used traditional medicine. In many Asian countries traditional medicine is widely used, even though Western medicine is often readily available. In Japan, $60-70 \%$ of allopathic doctors prescribe traditional medicines for their patients. The number of visits to providers of Complementary Alternative Medicine (CAM) now exceeds by far the number of visits to all primary care physicians in the US (WHO 1999, 2002).

Complementary alternative medicine is also becoming more and more popular in many developed countries. Forty-two percent of the population in the US have used complementary alternative medicine at least once (WHO 1998), and a national survey reported the use of at least one of 16 alternative therapies increased from $34 \%$ in 1990 to $42 \%$ in 1997 (UNCTD 2000).

The expenses for the use of traditional and complementary alternative medicine are exponentially growing in many parts of the world. The 1997 out-of-pocket Complementary Alternative Medicine expenditure was estimated at US\$ 2,700 million in the USA. The world market for herbal medicines based on traditional knowledge is now estimated at US\$ 60,000 million (Breevort 1998).

Northern Peru is believed to be the center of the Central Andean Health Axis (Camino 1992), and traditional medicinal practices in this region are still an important component of everyday life (Bussmann 2006, Bussmann \& Sharon 2006, De Feo 1992, Joralemon \& Sharon 1993, Polia 1988, Sharon 1978, 1980, 1994, 2000, Sharon \& Bussmann 2006b). Traditional medicine is also gaining more and more respect by national governments and health providers. Peru's National Program in Complementary Medicine and the Pan American Health Organization recently compared complementary medicine to allopathic medicine in clinics and hospitals operating within the $\mathrm{Pe}$ ruvian Social Security System (EsSalud 2000).

According to WHO (2002), the sustainable cultivation and harvesting of medicinal species is one of the most important challenges for the next few years. The medicinal flora of Northern Peru is now well documented (Bussmann 2006, Bussmann \& Sharon 2006, 2007, Bussmann et al. 2007, Sharon \& Bussmann 2006 a,b). However, little has been determined about the origin of many of the plant species found in local markets, the effort involved in cultivation and/or wild harvesting, and the income flow to the initial collectors. The present study was undertaken with the hope of obtaining a more comprehensive understanding of exactly how medicinal plants encountered in the coastal markets of Northern Peru are brought to the consumer. Clarification was sought concerning wild-harvest techniques and impacts on natural habitats, source areas, as well as trade routes and vendor networks. The complexity of the contributing factors involved in a certain herbal medicine becoming available to the final consum- er was only partially understood within the framework of the Minority Health Disparity International Research Training (MHIRT-Peru) project, although many other aspects of available species and their uses had been documented during prior research. The important link between the coastal markets and the highland areas around Cajamarca (Fig. 1) were of special interest during this investigation, due to the prevalence of information suggesting that this region was a primary supplier of medicinal plants. It was also assumed that tracing the availability and supply of medicinal plant products would provide an indication of the vitality and sustainability of this important trade. This information could potentially be used to identify possible problems or trends in the future, with a focus on future conservation efforts.

\section{Methodology}

Due to time constraints during the 2007 season, the decision was made to conduct research in a "case study" format. Through the aegis of a traditional healer with whom the researchers have worked with since 2000 , contact was made with a primary informant with many years of experience in both the use and commerce of medicinal plants. After obtaining prior informed consent, informal interviews

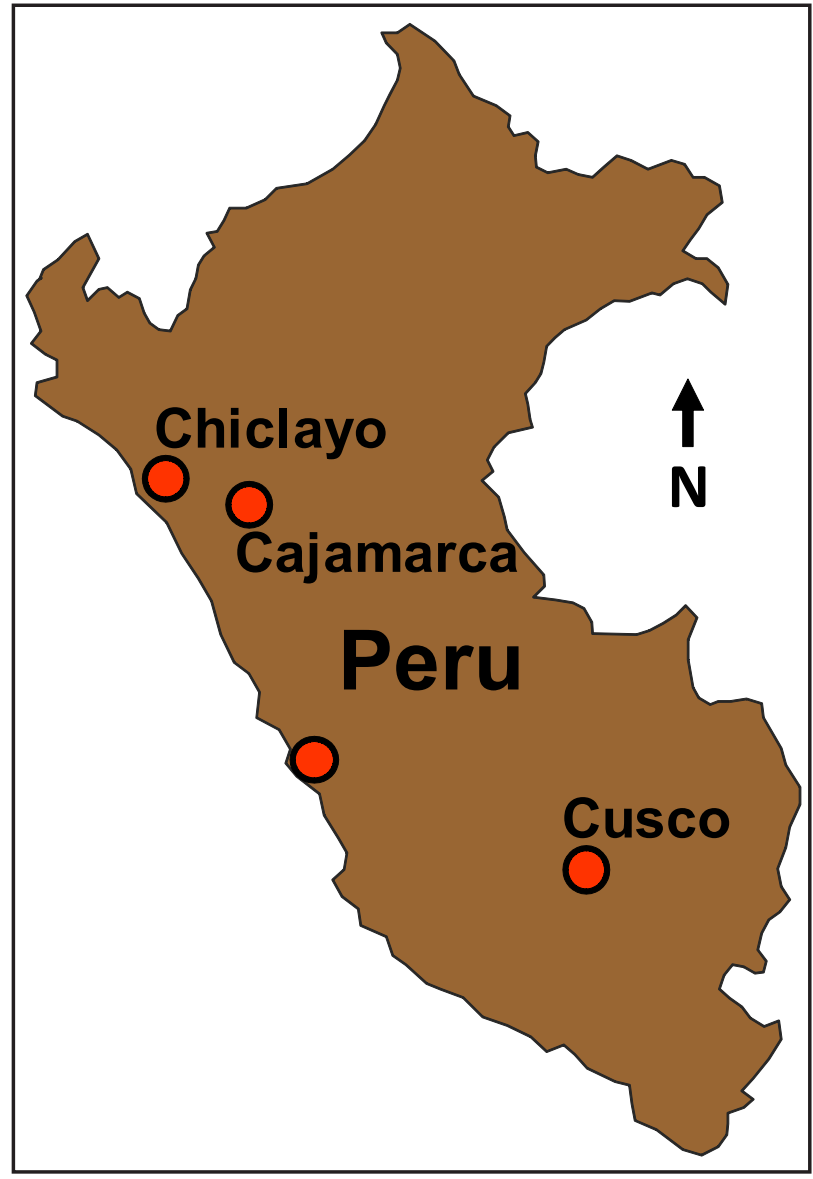

Figure 1. Study area in Cajamarca, Peru. 


\section{Revene et al. - From Sierra to Coast: Tracing the supply of medicinal plants in Northern Peru - A plant collector's tale}

were used while accompanying the informant in harvest activities, to points of purchase, and along the routes traveled during these processes. Information was subsequently compiled that documents the intricacies of the trade in medicinal plants. This format has the disadvantage of only giving a "snap-shot" view of this commerce from the point of view of one vendor. However, at the same time it provides valuable information concerning the day-to-day realities encountered by herbal vendors in general. Special attention was also paid to the economic aspects involved in the acquisition and sale of medicinal plants on a small scale.

Vouchers of all specimens were deposited at the Herbario Truxilliensis (HUT, Universidad Nacional de Trujillo), and Herbario Antenor Orrego (HAO, Universidad Privada Antenor Orrego Trujillo). In order to recognize Peru's rights under the Convention on Biological Diversity, especially with regard to the conservation of genetic resources in the framework of a study treating medicinal plants, the identification of the plant material was conducted entirely in Peru. No plant material was exported in any form whatsoever. The nomenclature of plant families, genera, and species follows the Catalogue of the Flowering Plants and Gymnosperms of Peru (Brako \& Zarucchi 1993). The nomenclature was compared to the TROPICOS database. Species were identified using the available volumes of the Flora of Peru (Macbride 1936-81), and reference material in the herbaria HUT and HAO.

\section{Results and Discussion}

\section{La Sierra - plant collection and purchase}

Julia Rita Guamán Aquino lives with her common-law husband, José Santos Ramírez Bardales, in the small community of Chigdén, in the municipality of San Juan, outside the city of Cajamarca. The area surrounding their home in the northern highlands of Peru is characterized by the typical high peaks of the Andes Mountains, as well as the associated steep and precipitous drops in elevation down to numerous river valleys. During the months of June-August, when this study was undertaken, the peaks surrounding their home on every side had already begun to turn noticeably brown and dry. The most productive months for the harvest of medicinal plants at this elevation (approximately 2600 meters above sea level) are April and May. However, the small valley basin of the Yamagual River where the couple resides remains green and vibrant year-round, supplied with sufficient water from both natural springs and diverted water from recent community development projects.

The area surrounding Julia and Santos's home serves as the region of supply for the numerous medicinal plants that they devote a large part of their time collecting, and purchasing from neighbors. The amount of land area tra- versed during harvest and purchase expeditions is impressive in size, as are the dramatic changes in elevation over short distances that are encountered. The Yamagual River Valley, and the mountainsides that encompass it, are where Julia and Santos encounter the 73 medicinal plant species that they identify as being able to harvest during the high production period of the year. They identified six sites as the best harvest areas, Chusap, El Higuerón, El Gavilán, El Marco, Manzanilla and Umagual, all existing within an estimated land area of $24 \mathrm{~km}^{2}$. The harvest and purchase sites visited were all reached by foot. Certain sites, such as El Gavilán, were sometimes reached by combis (collective transport minivans) that travel the section of the Cajamarca highway which passes through the region. A day's journey in search of the necessary medicinal plants could range from anywhere between a short morning venture, up to a 14-hour trek. Julia and Santos are owners of three small donkeys, but the majority of the loads that they transport were carried on their own backs. Such loads, estimated to weigh $18 \mathrm{~kg}$ (36.6lbs) or more, were simply placed on their shoulders and hauled the long distances necessary to reach their home.

The harvest techniques implemented during the collection of the sought-after plants at first appeared to be random to an outside observer. However, there were certain simple strategies that the couple used in order to insure that their harvest is sustainable. For example, upon encountering a juvenile specimen of a certain tree that would normally have been partially harvested, Julia explained that she was going to leave it untouched to make sure that it would be a more productive and reliable source of plant material in years to come. She also stated that, since it was the dry season, even more damage would be done by harvesting because the tree would not be able to respond as well to the physical trauma involved. However, for small annuals, conservation strategies seemed to be far less important. Many plants were pulled up completely by the roots, obviously precluding any further propagation. No attention was paid to whether or not a plant had already set seed, and in fact, many plants were selected specifically because they were still in flower to take advantage of the curative properties inherent in the flower itself. The only limiting factor on over-harvest of these annual species appears to be the distribution of the meandering paths walked during the collection process.

When asked if they had noticed any decline in the quantity or variety of certain plants in the area, the informants responded that the plant populations had always been stable, and that they had always been found in the same areas. This information appears to be valid, considering the responses given to inquiries regarding different harvest areas during which very specific information was given as to what species were in certain zones. This information apparently consistent from the time of their childhoods, when their parents and relatives also used the same harvest areas for the same species (the couple are both in 
their fifties.) It appears that the human impact upon the botanical resources in the area has so far been minimal and sustainable. It can be assumed that this is mainly due to the large land area in proportion to the small harvesting population of the local communities.

An important component in the acquisition of the medicinal plants that Julia took to market was the network of family and neighbors in the immediate area from whom she bought certain plant species. This was especially important during the dry months, when the normally varied selection of plants is limited and the distance necessary to encounter a given species becomes greater. It is this informal network that helped buffer Julia against unusually long treks, and helped to bolster the otherwise dwindling variety that is common during the dry season. She listed seven different households that were occasionally and informally contracted to supply medicinal plants during these dry months. The plants that were bought were both cultivated as well as wild-harvested. Many of the wild-harvested plants came from just outside the Yamagual River Valley area that Julia and Santos normally harvest, suggesting a "cost-benefit" relationship with local suppliers. Because the prices that Julia pays in the countryside are much lower than those that she pays in the urban market of Cajamarca, it becomes economically feasible for her and her husband to opt to buy a certain plant from a longdistance source, as opposed to making the journey themselves. This trade relationship creates more links farther into the mountains, with each supplier adding more distance traveled in the overall network, and each contributing to a more widely varied species selection.

Another important source of the medicinal plants that Julia took down to the coastal markets was the informal herbal market in the city of Cajamarca. This herbal market is very loosely configured within the larger vegetable and dry-goods street market, and is often highly ephemeral. Although the established days of purchase for the wholesale medicinal plant vendors who take their goods to the coastal market were Monday and Thursday, there was at least limited availability of medicinal plant materials every day of the week. As opposed to formal stands where the plants are sold, the trade mainly consisted in small-scale suppliers arriving with bundles of between one and seven varieties of plants, and selling to the awaiting wholesale buyers. This creates a system where the sellers come to the buyers, who appear to have prearranged contacts and pending orders. The women who came to sell to the wholesale buyers in Cajamarca were yet one more link in the extensive network of supply. Some of them came from communities up to five hours away, thus adding even more distance that any given plant can possibly travel before making it to the final consumer. One reason for the long distances that many of these plants travel was their seasonal scarcity at lower elevations, which had already begun to suffer the effects of the lack of rainfall. Many of the outlying supply communities are subject to more fa- vorable rainfall conditions, which allows for a longer harvest season. Communities represented on a given day in the Cajamarca market included Porcón, Combayo, Rosa Mayo, Otuzco, Puruay Alto and Guacacaris.

Almost all of the buyers and sellers were women, and transactions were typically rapid and to the point. Since the buyers were the ones who established the point of purchase along a certain section of sidewalk on the outskirts of the market, the course of the morning led to the increasing accumulation of plant material by each buyer at her specific location. Each wholesale buyer, of which there were on average between three and five during the duration of the study at this specific market, packaged their wares in large sacks as the morning progressed. Opportunistic sales were sometimes made to passers-by with a specific request, but most of the acquired plants were stowed away, awaiting the more profitable economic gains to be made in the coastal market of Moshoqueque in the city of Chiclayo. This activity usually occupied the entire morning, from the hours of 8AM to $1 \mathrm{PM}$.

\section{La Costa - plant sale in Chiclayo}

Julia has been selling medicinal plants in the market of Moshoqueque in Chiclayo for 16 years. Although her husband helped her with the collection of plants while in her home region, she typically made the journey down to the coastal market by herself. This is not to say that she was alone. On any given market day in Moshoqueque (Tuesdays and Fridays for the Cajamarca vendors), between three to five vendors arrived in each truck, with anywhere between four and seven trucks arriving from Cajamarca. The vendors all congregated at a meeting point on the outskirts of the city of Cajamarca in the afternoon on Mondays and Thursdays, after having made their purchases. The many large sacks that contained the plants were segregated by owner on the sidewalk beside the waiting transport truck, the bed of which measured $6 \mathrm{~m} \times 3 \mathrm{~m}$, and was enclosed by a high-walled wooden frame. The departure time was variable, depending upon the arrival of the different vendor and other cargo that was contracted for the journey. But eventually the loads were lifted and arranged in the truck bed, with some sacks of more delicate plant material being stowed on an overhead rack. The departure time was around 5:30PM, although this hour could sometimes vary to as late as 9PM. The vendors all rode in the bed of the truck along with their goods, each having brought along the blankets necessary to guard against the cold wind that would accompany them the entire six to seven hour journey to the coast.

The dusty street that runs along the outside of the stadium of the city of Chiclayo is the set-up point for the Cajamarca vendors, and is known as the Moshoqueque Market Annex. Arriving at 2:30AM in the morning, the women swung immediately into action, unloading their sacks with the help of the truck owner and assistants, as well as the 


\section{Revene et al. - From Sierra to Coast: Tracing the supply of medicinal plants in Northern Peru - A plant collector's tale}

young men with bike carts who were already waiting when the truck arrived. The individual locations used by each woman to set out her goods appeared to be respected by all, each area usually being identifiable by some sort of mark along the wall of the stadium, or other such landmark. After the small section of sidewalk and street to be occupied was swept off, plastic tarps or emptied sacks were placed on the ground. The different bundles of plants were then arranged on top, all being separated by variety. There did not seem to be any importance given to which plants were placed in the street-front rows, closest to the consumer. In fact, many of the more frequently requested plants were placed near the place where Julia was to be seated on the sidewalk. She also kept specially requested orders off to one side, awaiting the arrival of the client.
Julia's selling strategies were based heavily upon the concept of supply and demand. Amid the flurry of activity involved in setting out the different bundles of plants as quickly as possible, Julia made several walk-by surveys of her neighbor's selection. She quickly calculated which plants in her inventory were also very plentiful in her neighbor's selection on that day. She modified her asking price accordingly, making sure not to put herself at a loss by asking too high a price. In many cases this entailed selling plants for the exact same price she herself paid for them, and in a few cases she actually sold at a loss (see Table 1). This strategy was based on her walkthrough assessment of the day's market, and was utilized in order to avoid a heavy economic loss, or having to deal with a large excess quantity of plants at the end of the

Table 1. Plants collected and average price sold by Julia in the market of Moshoqueque in Chiclayo, Peru. wild= wild harvested. Plants sold at a loss are noted in red.

\begin{tabular}{|c|c|c|c|c|}
\hline \multirow[t]{2}{*}{ Scientific name } & \multirow[t]{2}{*}{ Common name } & \multicolumn{3}{|c|}{$\begin{array}{l}\text { Price per plant bundle } \\
\text { (Nuevo soles) }\end{array}$} \\
\hline & & Buying & Selling & Profit \\
\hline Alternanthera porrigens (Jacquin) Kuntze (Amaranthaceae) & moradilla & wild & 0.25 & 0.25 \\
\hline Ammi visnaga (L.) Lam. (Apiaceae) & bisnaga & wild & 0.25 & 0.25 \\
\hline Apium graveolens L. (Apiaceae) & apio & 0.5 & 0.5 & 0 \\
\hline Borago officinalis L. (Boraginaceae) & borraja & 0.3 & 0.5 & 0.2 \\
\hline Capsella bursa-pastoris (L.) Medic (Brassicaceae) & bolsa de pastor & 0.3 & 0.25 & 0.05 \\
\hline Cynara cardunculus L. (Asteraceae) & alcachofa & 0.25 & 0.25 & 0 \\
\hline Desmodium molliculum (H.B.K.) DC. (Fabaceae) & pie de perro & 0.3 & 0.4 & 0.4 \\
\hline Dodonaea viscosa Jacquin (Sapindaceae) & chamana & wild & 0.3 & 0.3 \\
\hline Ephedra americana H. \& B. (Ephedraceae) & diego lopez & wild & 0.2 & 0.2 \\
\hline Equisetum bogotense (H.B.K.) Kunth (Equisetaceae) & cola de caballo & 0.25 & 0.2 & -0.05 \\
\hline Erodium cicutarium (L.) L'Herit. (Geraniaceae) & agujilla & 0.3 & 0.3 & 0 \\
\hline Foeniculum vulgare P. Miller (Apiaceae) & hinojo & 0.375 & 0.2 & -0.175 \\
\hline Gentianella graminea (H.B.K.) Fabris (Gentianaceae) & chimchim & 0.3 & 0.25 & -0.05 \\
\hline Geranium ayavacense Willd ex H.B.K. (Geraniaceae) & patuchaque & 0.25 & 0.5 & 0.25 \\
\hline Lepechinia meyenii (Walpers) Epling (Lamiaceae) & salvia & 0.25 & 0.3 & 0.05 \\
\hline Lobelia decurrens Cavaniles (Lobeliaceae) & contoya & 0.03 & 0.2 & 0.17 \\
\hline Malva sylvestris L. (Malvaceae) & malva & 0.25 & 0.25 & 0 \\
\hline Matricaria frigidum (HBK) Kunth (Asteraceae) & manzanilla dulce & 0.3 & 0.75 & 0.45 \\
\hline Matricaria recutita L. (Asteraceae) & manzanilla amarga & 0.175 & 0.25 & 0.175 \\
\hline Mauria heterophylla H.B.K. (Anacardiaceae) & tres hojas & wild & 0.25 & 0.25 \\
\hline Melissa officinalis L. (Lamiaceae) & toronjil & 0.25 & 0.6 & 0.35 \\
\hline Minthostachys mollis Griesebach (Lamiaceae) & muña & 1 & 0.25 & -0.75 \\
\hline Nectandra floribunda Nees (Lauraceae) & eshpingo & 0.1 & 0.2 & 0.1 \\
\hline Nerium oleander L. (Apocynaceae) & laurel & 0.375 & 0.25 & -0.175 \\
\hline Otholobium glandulosum (L.) Grimes (Fabaceae) & culén & 0.15 & 0.25 & 0.1 \\
\hline Pellaea ternifolia C. Chr. (Adiantaceae) & cuti-cuti & 0.17 & 0.25 & 0.08 \\
\hline Perezia multiflora (H. \& B.) Lessing (Asteraceae) & escorcionera & 0.15 & 0.25 & 0.1 \\
\hline
\end{tabular}




\begin{tabular}{|c|c|c|c|c|}
\hline \multirow[t]{2}{*}{ Scientific name } & \multirow[t]{2}{*}{ Common name } & \multicolumn{3}{|c|}{$\begin{array}{l}\text { Price per plant bundle } \\
\text { (Nuevo soles) }\end{array}$} \\
\hline & & Buying & Selling & Profit \\
\hline Petroselinum crispum (Miller) A.W. Hill (Apiaceae) & perejil & 0.3 & 0.3 & 0 \\
\hline Rorippa nasturtium-aquaticum (L.) Hayek (Brassicaceae) & berros & 0.025 & 0.2 & 0.175 \\
\hline Rosmarinus officinalis L. (Lamiaceae) & romero & 0.2 & 0.3 & 0.1 \\
\hline Ruta graveolens L. (Rutaceae) & ruda & 0.3 & 0.5 & 0.2 \\
\hline Salvia rosmarinifolia Hort. ex G. Don. (Lamiaceae) & romero de campo & 0.12 & 0.2 & 0.08 \\
\hline Sambucus peruviana H.B.K. (Caprifoliaceae) & sauco & 0.25 & 0.2 & -0.05 \\
\hline Satureja pulchella (H.B.K.) Briquet (Lamiaceae) & panizara & 0.1 & 0.2 & 0.1 \\
\hline Scabiosa atropurpurea L. (Dipsacaceae) & ambarina & 0.2 & 0.5 & 0.3 \\
\hline Spartium junceum L. (Fabaceae) & retama & 0.25 & 0.25 & 0 \\
\hline Taraxacum officinale Wiggers (Asteraceae) & diente de león & 0.12 & 0.2 & 0.08 \\
\hline \multirow[t]{3}{*}{ Urtica magellanica A. Jussieu ex Poiret (Urticaceae) } & ortiga & 0.3 & 0.5 & 0.2 \\
\hline & canilla wuangi & wild & 0.25 & 0.25 \\
\hline & chochocón & wild & 0.25 & 0.25 \\
\hline
\end{tabular}

day. She also paid close attention to which plants were in short supply in the market on that day, especially in the case of plants that she herself did not have. On more than one occasion throughout the morning Julia could be seen buying these short-supply plants from her neighboring vendors. The bundles that she bought were then often cut in half and sold at profit. Julia did all of this data collection mentally with no note-taking or other external means of calculation used. She could recite the amount purchased and price paid for each of the plants in her inventory, mentally calculate a justified and profitable asking price and give the uses and preparation instructions for each of her plants.

The first customers began to arrive at 3AM, with the activity picking up dramatically at around 5AM. The clients varied between people looking for one or two specific plants, of which they purchased just a bundle, to wholesale buyers. Although it fell outside the scope of this investigation, it can be assumed that the wholesale buyers who arrive at Moshoqueque to purchase plant species in bulk from the Cajamarca vendors are also involved in transporting the plants some distance, to then be resold at a profit. Julia stood firm on her asking price throughout the morning, denying the frequent requests for discounts. This strategy begins to make sense when one analyzes the overall profit that she would take away at the end of the day. Table 2 gives an averaged breakdown of Julia's expenditures and profits, as well as an average daily wage, based upon her normal three-day cycle (one day collecting and buying around her home, one day purchasing in the $\mathrm{Ca}$ jamarca market, and one day selling in Moshoqueque.) This calculation is based upon a "best case scenario," giving figures that would be true of a hypothetical day, where Julia might sell all of her stock at the asking prices. Real world variables are discussed below, and are analyzed in
Table 3. The daily wage figure does not include the contributing work done by her husband.

It should be noted that on some days Julia's sales were well below average. She arrived, for example, with six large sacks of plants, but by 11AM only half of the overall selection had been sold. Since the Moshoqueque market only functions in the morning, she was faced with packing up her remaining stock and transporting it to other wholesale buyers. This is one of the risks that she runs as a middleman, and the effects are quickly felt economically. The only option that she had was to go to the Mer-

Table 2. Average non-variable net profit and daily income (complete sale of inventory) earned by Julia in the market of Moshoqueque in Chiclayo, Peru.

\begin{tabular}{|c|c|c|}
\hline \multirow{2}{*}{$\begin{array}{l}\text { Net-Profit Statement } \\
\text { Expenses }\end{array}$} & \multicolumn{2}{|c|}{ Amount } \\
\hline & $\begin{array}{r}\text { Nuevo } \\
\text { Soles }\end{array}$ & US\$ \\
\hline Plants & 177.60 & 56.56 \\
\hline Transport Chigden/Cajamarca & 4 & 1.27 \\
\hline Transport Cajamarca/Chiclayo & 20 & 6.37 \\
\hline Transport Chiclayo/ Cajamarca & 5 & 1.59 \\
\hline Total Expenses & S206.60 & $\$ 65.80$ \\
\hline \multicolumn{3}{|l|}{ Income } \\
\hline Plants (without variable) & 267.35 & 85.14 \\
\hline Total Income & S267.35 & $\$ 85.14$ \\
\hline Net profit (without variable) & S60.75 & $\$ 19.35$ \\
\hline $\begin{array}{l}\text { Daily income (based on } \\
\text { a three day cycle): }\end{array}$ & S20.25 & $\$ 6.45$ \\
\hline
\end{tabular}




\section{Revene et al. - From Sierra to Coast: Tracing the supply of medicinal plants in Northern Peru - A plant collector's tale}

Table 3. Average variable net profit and daily income (below average sale) earned by Julia in the market of Moshoqueque in Chiclayo, Peru.

\begin{tabular}{|c|c|c|}
\hline Net-Profit Statement & \multicolumn{2}{|c|}{ Amount } \\
\hline Expenses & $\begin{array}{r}\text { Nuevo } \\
\text { Soles }\end{array}$ & US\$ \\
\hline Plants & 177.60 & 56.56 \\
\hline Transport Chigden/Cajamarca & 4 & 1.27 \\
\hline Transport Cajamarca/Chiclayo & 20 & 6.37 \\
\hline Transport Chiclayo/ Cajamarca & 5 & 1.59 \\
\hline Total Expenses & S206.60 & $\$ 65.80$ \\
\hline \multicolumn{3}{|l|}{ Income } \\
\hline Plants (without variable) & 233.00 & 74.20 \\
\hline Total Income & S233.00 & $\$ 74.20$ \\
\hline Net profit (with variable) & S26.40 & $\$ 8.41$ \\
\hline $\begin{array}{l}\text { Daily income (based on } \\
\text { a three day cycle): }\end{array}$ & S8.80 & $\$ 2.80$ \\
\hline
\end{tabular}

cado Modelo municipal market, also in Chiclayo, and try to sell her remaining stock to the permanent medicinal plant vendors there. Since she must pay the truck owner based upon the quantity of merchandise she transports on any given trip, either to or from Chiclayo, it was prohibitive for her to take the remaining plants back to her home to be resold on the next market day. Also, because all of her selection was fresh plant material, she would inevitably lose a substantial amount of it due to wilting or rotting in the interim. Upon arriving at the Mercado Modelo she ran into more difficulties because of the fact that none of the buyers at the permanent medicinal plant stands there were interested in buying from her. She then resorted to taking her plants back to the few herbal vendors in the official and permanent section of the Mercado Moshoqueque. It was there that she was able to sell her plants, but only at a price substantially lower than the original asking price. Table 3 shows us the difference in profit between a "best case scenario" market day and one during which sales are below average. The difference is striking, and its economic implications are obvious.

\section{Conclusions}

When analyzed, the distances traveled, time spent, and energy expended during the commerce of medicinal plants in Northern Peru are astounding figures. The individual consumer in the coastal markets has little reason to comprehend all of the factors that are involved in a certain plant being available for his or her use. However, it is the intricate and expansive network of trade occurring in the highland areas that makes such a thing possible.
As we have seen, the individual's role in this process is a labor-intensive endeavor. It can also become a risky financial investment, depending upon market conditions on a given day. Although Julia's low profit margin during the period that the data were collected might be an aberration, it indicates how delicate the different links in this network can be. The interconnectivity of primary suppliers/ harvesters, wholesale buyers/vendors and customers is as wide reaching as it is complex.

Although there were no negative human impacts identified during visits to harvest sites, this does not preclude the possibility that these effects could manifest at the same locations in the future. A more focused study analyzing land area proportional to harvesting populations could provide a better indication as to the sustainability of this activity. Changing water and land-use issues, as well as climatic conditions would also be a necessary components in any further study.

\section{Acknowledgements}

The authors gratefully acknowledge the financial support of the fieldwork through the Allemal Foundation and MIRT (Minority International Research and Training), MHIRT (Minority Health Disparity International Research and Training), a grant from the National Institutes of Health (Fund: 54112B MHIRT Program, Grant: G0000613), administered by the Fogarty International Center for Advanced Studies in Washington, D.C.

None of the work would have been possible without the invaluable collaboration of our Peruvian colleagues Julia Rita Guamán Aquino and José Santos Ramírez Bardales.

\section{Literature Cited}

Brako L. \& J.L. Zarucchi 1993. editors of Catalogue of the Flowering Plants and Gymnosperms of Peru. Missouri Botanical Garden, Saint Louis, MO.

Breevort, P. 1998. The Booming U. S. Botanical Market: A New Overview. HerbalGram 44:33-46.

Bussmann, R.W. 2006. Manteniendo el balance de naturaleza y hombre: La diversidad florística andina y su importancia por la diversidad cultural - ejemplos del Norte de Perú y Sur de Ecuador. Arnaldoa 13:382-397.

Bussmann, R.W. \& D. Sharon. 2006. Traditional plant use in Northern Peru: Tracking two thousand years of health culture. Journal of Ethnobiology and Ethnomedicine 2:47.

Bussmann, R.W. \& D. Sharon. 2007. Plants of the Four Winds - The magic and medicinal flora of Peru. Plantas de 
los cuatro vientos - La flora mágica y medicinal del Perú. Trujillo, Graficart.

Bussmann, R.W., D. Sharon \& A. Lopez. 2007. Blending Traditional and Western Medicine: Medicinal plant use among patients at Clinic Anticona in El Porvenir, Peru. Ethnobotany Research and Applications 5:185-199.

Camino, L. 1992. Cerros, plantas y lagunas poderosas: La medicina al norte del Perú. Lluvia Editores, Lima.

De Feo, V. 1992. Medicinal and magical plants on northern Peruvian Andes. Fitoterapia 63:417-440.

EsSalud/Organización Panamericana de Salud. 2000. Estudio Costo-Efectividad: Programa Nacional de Medicina Complementaria. Seguro Social de Es Salud. EsSalud/Organización Panamericana de Salud, Lima.

Joralemon, D. \& D. Sharon. 1993. Sorcery and Shamanism: Curanderos and Clients in Northern Peru. University of Utah Press, Salt Lake City.

McBride J.F. 1936-1981. Editor of Flora of Peru. Fieldiana: Botany. Field Museum of Natural History, Chicago.

Polia, M. 1988. Las Lagunas de los Encantos - Medicina Tradicional Andina en el Peru septentrional. CePeSer. Lima.

Sharon, D. 1978. Wizard of the Four Winds: A Shaman's Story. Free Press, New York.

Sharon, D. 1980. El Chamán de los Cuatro Vientos. Siglo veintiuno editores, México.

Sharon, D. 1994. Tuno y sus colegas: notas comparativas. Pp.128-147 in En el Nombre del Señor: Shamanes, demonios y curanderos del norte del Perú. Edited by $\mathrm{L}$. Millones \& M. Lemlij. Australis S.A., Lima.

Sharon, D. 2000. Shamanismo y el Cacto Sagrado - Shamanism and the Sacred Cactus. San Diego Museum Papers 37, 2000.

Sharon, D. \& R.W. Bussmann. 2006a. Avances de la etnobotánica en Trujillo, Perú: El programa MHIRT. Arnaldoa 13:398-406.

Sharon, D. \& R.W. Bussmann. 2006b. Plantas Medicinales en la Obra del Obispo Don Baltasar Jaime Martínez Compagñon (Siglo XVIII). Pp. 147-165 in Desde el exterior: El Peru y sus estudios. Edited by L. Millones, L. \& T. Kato, Tercer Congreso Internacional de Peruanistas, Nagoya, 2005. UNMSM.

United Nations Conference on Trade and Development. 2000. Systems and National Experiences for Protecting Traditional Knowledge, Innovations and Practices. Background Note by the UNCTAD Secretariat. United Nations Conference on Trade and Development, Geneva. (document reference TD/B/COM.1/EM.13/2).

World Health Organization. 1998. Report: Technical Briefing on Traditional Medicine. Forty-ninth Regional Committee Meeting, Manila, Philippines, 18 September 1998. Manila, WHO Regional Office for the Western Pacific.

World Health Organization. 1999. Consultation Meeting on Traditional Medicine and Modern Medicine: Harmonizing the Two Approaches. World Health Organization, Geneva. (document reference (WP)TM/ICP/TM/001/RB/98$\mathrm{RS} / 99 / \mathrm{GE} / 32(\mathrm{CHN}))$.

World Health Organization. 2002. WHO Traditional Medicine Strategy 2002-2005. World Health Organization, Geneva. 